\title{
Hepatitis B Core Antibody: Role in Clinical Practice in 2020
}

\author{
Robert G. Gish ${ }^{1}$ (D) $\cdot$ Syed Abdul Basit ${ }^{2} \cdot$ John Ryan ${ }^{2} \cdot$ Altaf Dawood $^{3} \cdot$ Ulrike Protzer $^{4,5}$
}

Published online: 11 July 2020

(C) The Author(s) 2020, corrected publication 2020

\begin{abstract}
Purpose of Review It is crucial for clinicians to understand the need to screen for hepatitis B core antigen (anti-HBc status), proper interpretation of HBV biomarkers, and that "anti-HBc only" indicates HBV exposure, lifelong persistence of cccDNA with incomplete infection control, and potential risk for reactivation.

Findings Many common misconceptions exist, including that tests for anti-HBc have high false-positive rates, that patients with anti-HBc alone or occult hepatitis B may profit from "vaccine boosting" to achieve immune control of $\mathrm{HBV}$, and that anti- $\mathrm{HBc}(+$ )/anti-HBs(+) patients have cleared HBV when they have actually achieved immune control, while HBV persists in some hepatocytes and can reactivate.

Summary This review breaks down several common misconceptions regarding anti-HBc with the most recent evidence. In addition, current best strategies for anti-HBc testing and interpretation are reviewed and summarized.
\end{abstract}

Keywords Hepatitis B core antibody $\cdot$ Anti-HBc testing $\cdot \mathrm{HBV}$ biomarkers $\cdot \mathrm{HBV}$ screening $\cdot \mathrm{HBV}$ reactivation

\section{Introduction}

Approximately 2 billion people worldwide have been infected with hepatitis B virus (HBV) as indicated by the presence of antibodies to the hepatitis B core antigen (anti-HBc) [1,2]. Any indication of necroinflammatory liver disease, either by elevated serum ALT activity or by liver histology in patients who are hepatitis B surface antigen (HBsAg) positive for at least 6 months, is referred to as chronic hepatitis B (CHB) [3]. Historically (before 2002), anti-HBc tests had a high rate of

Robert G. Gish and Syed Abdul Basit contributed equally to this work.

Robert G. Gish and Syed Abdul Basit are co-first authors

This article is part of the Topical Collection on Hepatitis B

Robert G. Gish

rgish@robertgish.com

1 Hepatitis B Foundation, Doylestown, PA, USA

2 Comprehensive Digestive Institute of Nevada, Las Vegas, NV, USA

3 Department of Gastroenterology and Hepatology, University of Nevada School of Medicine, Las Vegas, NV, USA

4 Institute of Virology, Technical University of Munich/Helmholtz Zentrum München, Munich, Germany

5 German Center for Infection Research (DZIF), Munich partner site, Munich, Germany false positives which led to concerns about lack of vaccine protection or incorrect assessment of patients at risk for reactivation. Fortunately, since 2002, the best anti-HBc tests have a false positive rate of $<2 / 1000$ even in low-risk individuals [4]. One potential scenario where the risk of false-positive testing may be increased is in the setting of intravenous immunoglobulin where passive antibody transfer may lead to false-positive testing before serial testing shows subsequent degradation of core antibodies [5]. To determine a patient's $\mathrm{HBV}$ status, HBsAg is always tested alongside anti-HBc and anti-HBs (Fig. 1). A positive HBsAg antigen indicates ongoing infection and infectivity. Initially, the majority of infections are hepatitis B e antigen ( $\mathrm{HBe} A g$ )-positive. During the course of a chronic infection, however, $\mathrm{HBeAg}$ is often lost. $\mathrm{HBeAg}$ loss, whether spontaneous or treatment-induced and with or without anti-HBe seroconversion, represents partial immune control of chronic HBV infection, often leading to a low replicative phase [3]. In later phases of disease, $\mathrm{HBeAg}$ loss is sometimes caused by viral variants or mutants. Total anti-HBc typically persists lifelong.

The development of HBsAg antibodies (anti-HBs) and anti-HBc with negative testing for HBsAg and HBV DNA indicates immune control of the virus. Positive anti-HBc in HBsAg(-) patients who lack anti-HBs is referred to as "anti$\mathrm{HBc}$ only" [6] or "anti-HBc alone" [7, 8], but may also be referred to as a "functional cure" of HBV infection during or after treatment $[9 \cdot \bullet]$. Individuals who test $\mathrm{HBsAg}(-)$ and anti- 
Fig. 1 Interpreting $\mathrm{HBsAg}$, Anti-HBs, and anti-HBc test results. Abbreviations: HBsAg, hepatitis B surface antigen; anti-HBc, hepatitis B core antibody; anti-HBs, hepatitis B surface antibody; HBV, hepatitis B virus

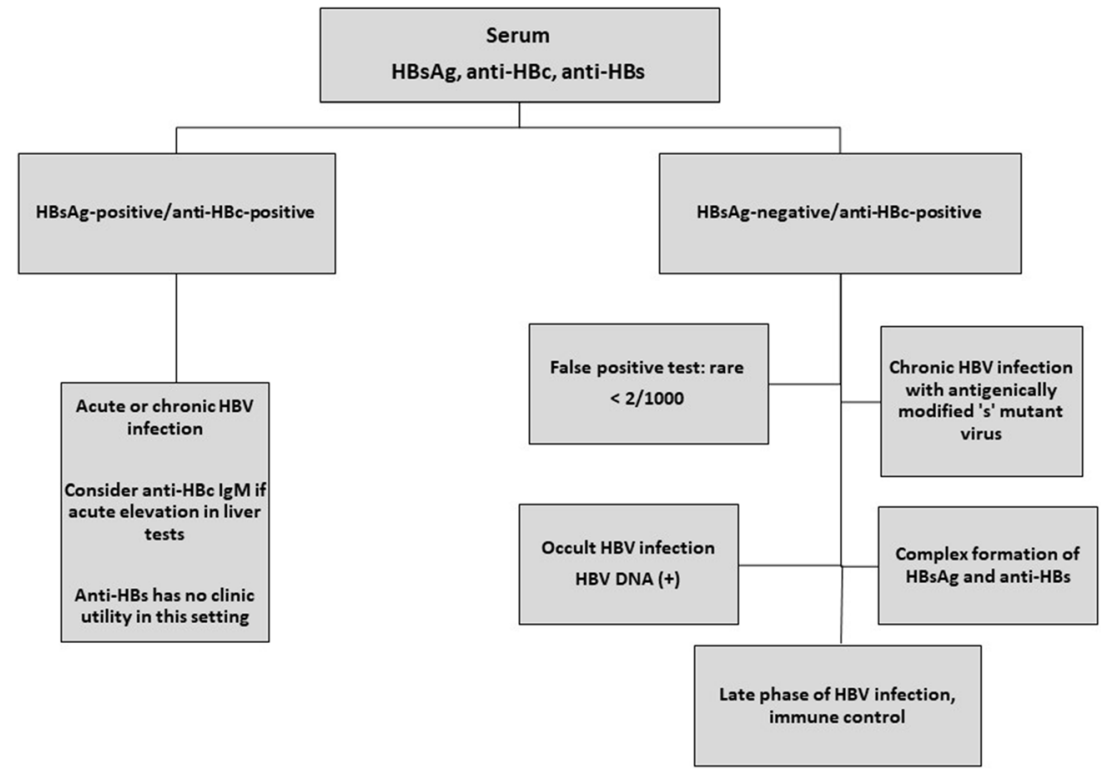

$\mathrm{HBc}(+)$ in whom HBV DNA in the blood or replicationcompetent HBV DNA in the liver is still present, the patient remains infectious and has seropositive occult $\mathrm{HBV}$ infection (OBI) [10].

In CHB patients with normal ALT and undetectable serum HBV DNA and in patients who have cleared HBsAg, cccDNA persists, and liver biopsy typically shows persistent cccDNA HBV in hepatocytes and mononuclear cells [11]. Although cccDNA levels may decrease over time under long-term NUC therapy [12,13], there is no evidence for complete elimination of cccDNA and thus no clearance or "cure" of infection. Intranuclear cccDNA persists, serving as a template for transcription of a number of HBV RNAs including core antigen [14]. HBsAg can also be produced from an integrated virus so clearance of cccDNA may not completely abrogate HBsAg production [15-17]. Currently available tests lack sensitivity and specificity to detect persistent virus cccDNA; thus, a negative test for liver tissue cccDNA does not indicate clearance of cccDNA [18]. Even loss of HBsAg does not indicate an elimination or silencing of cccDNA because circulating HBsAg may be complexed by anti-HBs antibodies and not be detectable by standard tests. Most frequently, a combination of viral and immune mechanisms explain the persistence of HBV cccDNA at low levels in patients who are anti-HBs(+)/anti-HBc(+) and $\mathrm{HBsAg}(-)$ and in patients who are anti-HBc(+) only.

\section{Anti-HBc During the Natural Course of HBV Infection}

After acute HBV infection, chronic infection (defined by HBsAg persistence for more than 6 months) develops in > $90 \%$ of infants born to infected mothers positive for HBeAg, in approximately $30 \%$ of children infected between ages 1 and
4 years, and in $\leq 5 \%$ of adults [19]. $\operatorname{HBeAg}(-)$ mothers can also transmit $\mathrm{HBV}$, with either $\mathrm{HBeAg}(+)$ or $\mathrm{HBeAg}(-)$ infection in the newborn [20]. In adults who do not develop chronic infection after exposure to HBV, both anti-HBc and anti-HBs typically develop. Along with T cells, these antibodies help to control the infection with viral replication significantly suppressed.

With acute HBV infection, after an incubation period of 4 10 weeks, HBsAg becomes detectable in the blood, typically with measurable HBV DNA [21]. Shortly after HBsAg becomes positive, the first antibody to core antigen (IgM anti$\mathrm{HBc}$ ) appears [22]. Because hepatitis B core antigen ( $\mathrm{HBcAg}$ ) is the most immunogenic component of HBV, high levels of first IgM anti-HBc and then IgG anti-HBc are produced. Anti$\mathrm{HBc}$, usually determined as total $\operatorname{IgM}$ and $\operatorname{IgG}$ antibodies, is considered the most sensitive and reliable markers of HBV exposure. During acute infection, the anti-HBc IgM increases rapidly. Thus, anti-HBc IgM is part of the first-line testing of HBsAg-positive patients with high ALT with or without liver dysfunction [23]. Although commonly disappearing after 612 months, anti-HBc IgM may become detectable again in a hepatitis flare during chronic infection, making clinical interpretation of whether it is an acute or a chronic infection flare sometimes different. High titers, however, indicate an acute infection [24-26].

In ongoing HBV infection, anti-HBc is detected together with HBsAg. While HBsAg may disappear, anti-HBc IgG commonly persists for life even in "resolved" HBV infection [22], probably due to the persistence of HBV in the form of cccDNA and low levels of core antigen production stimulating host B cells [27-29]. Thus, anti-HBc is useful for population-based HBV screening to determine exposure rates, and should be part of HBV testing panels for all patients in any population deemed at risk by current $\mathrm{WHO}$ or $\mathrm{CDC}$ guidelines 
to allow for better interpretation of results and appropriate linkage to care.

The following phases of infection can be delineated based on serum testing. The interpretation of anti-HBc test results are outlined throughout [30].

(1) High-viremic chronic infection: $\operatorname{HBs} A g(+), \operatorname{HBeAg}(+)$, normal ALT, and usually HBV DNA $>10^{7} \mathrm{IU} / \mathrm{ml}$

(2) $\operatorname{HBeAg}(+)$ chronic hepatitis B: elevated ALT usually with HBV DNA $10^{4}-10^{7} \mathrm{IU} / \mathrm{ml}$; [3]

(3) $\mathrm{HBeAg}(-)$ chronic hepatitis B: $\operatorname{HBsAg}(+)$ but $\mathrm{HBe} \mathrm{Ag}(-)$, and often anti-HBe(+), HBV DNA-positive, elevated ALT

(4) $\mathrm{HBeAg}(-)$, low viremic persistent infection due to partial immune control: $\mathrm{HBsAg}(+)$ but $\mathrm{HBeAg}(-)$, normal ALT, and usually low levels of HBV DNA $(<2000$ IU/ $\mathrm{ml}$ or $<10^{4}$ copies $/ \mathrm{ml}$ )

(5) Immune control: $\mathrm{HBsAg}(-)$, anti-HBc(+), and anti$\mathrm{HBs}(+)$

(6) Anti-HBc only: [7] neither $\mathrm{HBsAg}(+)$ nor anti-HBs(+) with variable detection of HBV DNA (OBI if HBV DNA is positive)

Testing for HBV in pregnant mothers is the standard of care, and determining the phase of disease helps in preventing HBV transmission and care of the mother. In the setting of potential mother-to-child transmission, European and American guidelines currently recommend HBIG administration and HBV vaccination to prevent transmission to the newborn [31, 32]. In high viremic, pregnant women tenofovir treatment has been proven safe and efficacious to reduce mother-to-child transmission.

Hoofnagle et al. showed that serum anti-HBc was a marker for high-risk blood donors who could transmit HBV, that anti$\mathrm{HBc}$ was associated with transfusion-associated HBV transmission, and that anti-HBc testing and blood donor elimination can prevent $\mathrm{HBV}$ transmission when used for blood bank screening $[33 \cdot, 34]$. Because of its high sensitivity, anti-HBc identified potentially infectious donors missed by HBsAg testing before viral DNA with nucleic acid testing (NAT) became available. Using early anti-HBc tests, substantial questions emerged about the test's specificity because the anti-HBconly status was poorly understood. This resulted in attempts to vaccinate anti-HBc(+) patients to stimulate anti-HBs production and to "test" those with previous exposure to HBV and memory for anti-HBs production, where the test is performed shortly after vaccination. This practice, however, consumes resources and is not known to have any clinical benefit. Subsequent generations of anti-HBc tests used a broad spectrum of core antigens, increasing the test's ability to accurately detect anti-HBc. Very sensitive PCR testing and robust patient clinical profiles proved the very high sensitivity and specificity (99.8\%) of the new generation test including accurate use in low-risk patients [4].

First introduced in the USA in 1986, anti-HBc is often used for blood screening (often supplemented with HBV DNA PCR tests) $[35,36]$. Currently, NAT testing is preferred for blood screening as a sensitive test but is often not available in resource-constrained settings due to cost, and thus anti-HBc is used in these cases, despite lower sensitivity. Blood banks in western countries with HBsAg prevalence of less than $1 \%$ added anti-HBc to screening markers due to the long window phase between clearing HBsAg, and the development of measurable anti-HBs as well as the rare occurrence of OBI as defined by HBV DNA in $\mathrm{HBsAg}(-)$ patients where HBV DNA is only intermittently detectable [37, 38]. Identifying donors with recent hepatitis B infection is very important for blood safety, and knowledge of this "window" helped clinicians to appropriately manage patients in the window period and monitor for anti-HBs seroconversion and OBI [39]. Widespread screening with anti-HBc has resulted in a marked decrease in transfusion-related HBV transmission [40].

Interestingly, the World Health Organization (WHO) at present does not recommend anti-HBc as a screening test for blood donors where sensitive PCR testing is available [41•]. The 2018 American Association for the Study of Liver Diseases (AASLD) guidelines also do not recommend general anti-HBc testing based on historical problems with anti-HBc specificity. The WHO rationale for this is that there would then be a requirement for distinguishing between donors with resolved infection (considered "non-infectious" by WHO) and infectious donors and that in nations endemic for HBV, the prevalence of anti- $\mathrm{HBc}$ would be high and result in "unnecessary" discard of blood units. WHO assumes that anti-HBs may indicate better virus control and lower risk of transmission, so that all anti-HBc(+) donations would have to then be tested for anti-HBs to determine "infectiousness."

A retrospective analysis of $>30$ million blood donations in Germany indicated that anti-HBc testing improved blood safety in a low HBV-prevalence region and allowed the initiation of rational PCR testing [42]. In a high-prevalence region such as South China, however, anti-HBc screening may impair blood supply and ultra-sensitive PCR screening may be required [43॰]. A recent study from Japan indicated that anti$\mathrm{HBc}$-positive blood donations can be safely used if they contained anti-HBs titer of $>200 \mathrm{mIU} / \mathrm{ml}$ [44]. This would argue for anti-HBc testing in combination with anti-HBs quantification.

\section{Anti-HBc Test Performance and Utility}

Although historically there were many versions of anti-HBc tests with varying levels of specificity, most countries and labs are now using state-of-the-art FDA-cleared or CE-marked 
assays. These current anti-HBc tests (e.g, the Architect II system) are more than $99.8 \%$ specific for blood donors and thus indicative of residual disease (cccDNA) and a clear lack of need for or benefit from HBV vaccination [44, 45]. Thus, anti$\mathrm{HBc}$ is now the most sensitive serological test for screening of blood donors and to decide if a patient has ever been exposed to HBV with high specificity. There are no available performance data on regional anti-HBc tests that are not $\mathrm{CE}$ marked or FDA cleared.

Further test improvement has focused on determining the level of anti-HBc. The quantitative serum level of anti-HBc may be beneficial for decision-making in challenging clinical situations, including determining the phase of HBV infection, and may be a predictor of on treatment response to NUCs and interferon [46 ${ }^{\circ}$. Anti-HBc levels correlate with levels of HBV DNA, such that individuals with lower anti-HBc levels are more likely to have undetectable HBV DNA levels [47]. The current understanding and utility of quantitative anti$\mathrm{HBc}$ in patient care and decision-making are summarized in Table 2.

A true cure of HBV infection may not be feasible because HBV DNA is in the nucleus as the episomal form of cccDNA and integrated into the host genome producing HBsAg. Even among persons who have recovered from acute HBV infection, viral covalently closed circular DNA (cccDNA) can still be detected in the liver, explaining the reactivation of HBV replication when these "recovered" persons are profoundly immunosuppressed or in other clinical settings [9, 48]. "Functional cure" or "immune control" may be a more appropriate description. This explains why in patients who were infected with HBV-whether they resolved the infection or became chronic-the available prophylactic hepatitis $B$ vaccine does not show any clinical benefit $[49,50]$. Currently, there are no peer-reviewed publications to support vaccine "boosting" in anti-HBc-positive patients with negative or low anti-HBs. Anti-HBs cannot prevent new HBV infection in these patients since they are already $\mathrm{HBV}$-infected and have remaining integrated or episomal HBV DNA in the liver [9]. However, newer vaccines that induce a different or broader immune response, in particular when activating $\mathrm{T}$ cell responses, may have to be evaluated more carefully in this regard $[51,52]$. The presence of an antibody response (antiHBs) after vaccination in these patients is cosmetic and does not have any known clinic benefit.

A higher titer of vaccine-induced anti-HBs clearly confers better protection from a new infection in patients who are anti$\mathrm{HBc}$ negative. This benefit is less clear for resolved HBV infection. A recent meta-analysis of natural infection in patients with anti-HBs titers at various levels now indicates that under immune suppression, anti-HBs levels predict protection from reactivation of $\mathrm{HBV}$ infection, with reactivation risk decreasing as the titer of anti-HBs increases [53]. Randomized trials, however, are still lacking to investigate if increasing
anti-HBs levels by vaccination in an anti- $\mathrm{HBc}(+)$ patient increases the level of immune control of an ongoing infection as opposed to the anti-HBs seen after natural infection. Anti-HBc can also indicate exposure to $\mathrm{HBV}$ after $\mathrm{HBV}$ vaccination and does not indicated vaccine failure unless HBsAg or HBV DNA becomes positive indicating productive HBV infection.

\section{Anti-HBc as a Biomarker of Occult Hepatitis B Infection}

In a recent review by Raimondo and colleagues from the 2018 Taormina workshop, OBI is defined as HBsAg-negative hepatitis B with detectable HBV DNA in the liver or blood [10]. They further go on to subdivide into seronegative or seropositive OBI. Seropositive OBI, defined as those who are anti$\mathrm{HBc}$ and/or anti-HBs positive, comprises the majority of individuals affected. Those defined as seronegative are negative for both anti-HBc and anti-HBs, and comprise $1-20 \%$ of all $\mathrm{OBI}$ cases. Because anti-HBc is the most common seromarker in OBI individuals, screening for anti-HBc can help to identify $\mathrm{OBI}$, as described further below. The incidence of $\mathrm{OBI}$ in anti$\mathrm{HBc}(+)$ but anti-HBs(-) blood donors has been reported to be as high as $7-15 \%$ making this an important clinical issue [54]. The rate of OBI is significantly higher in patients coinfected with human immunodeficiency virus (HIV) or hepatitis $\mathrm{C}$ virus, and other risk factors for HBV [10, 55].

The gold standard for OBI diagnosis is detection of HBV DNA in the liver if a biopsy is available. However, HBV DNA should at least be measured in serum of all individuals suspected to have OBI regardless of their HBV serostatus even if they are HBsAg negative $[10,56]$. The most reliable OBI biomarker is low-level serum HBV DNA detected using a sensitive, quantitative HBV PCR assay [56]. As patients may cycle from HBV DNA-negative to positive repeat DNA testing in patients with "cryptogenic liver disease" may be necessary [37]. Currently, detecting HBV DNA can be a challenge in severely resource-limited countries [55]. Where sensitive or quantitative HBV DNA PCR is not available, anti$\mathrm{HBc}$ can be used as a surrogate marker to predict OBI in $\mathrm{HBsAg}(-)$ patients with elevated ALT. Although anti-HBc is not an ideal OBI biomarker, it indicates the risk [56].

Anti-HBc alone may also be the result of HBV variants evolving that result in production of modified "S" proteins not detected with standard assays; [30] coinfection with other liver-tropic viruses as has been shown with $\mathrm{HBV} / \mathrm{HCV}$ coinfection; [57] formation of HBsAg-anti-HBs immune complexes that standard commercial assays cannot detect; [58] and low anti-HBs levels that result from loss of the capacity to produce these antibodies due to immune senescence. A person with anti-HBc only should be considered infected with HBV with a low risk of transmission perinatally, sexually and via blood transfusion if qHBV DNA is low or undetectable; 
however, solid organ transplant transmission is a real risk [34, 59]. Conversion of patients from anti-HBc negativity to anti$\mathrm{HBc}$ positivity was common after intravenous immunoglobulin administration [60•]. Therefore, positive anti-HBc tests done shortly after intravenous immunoglobulin infusion should be interpreted with caution because it might indicate passive transfer instead of true infection. However, the probability of a positive test decreased with time since infusion with a very high anti-HBc usually disappearing within 2 3 months [60].

Anti-HBc has been thought to possibly indicate increased risk of hepatocellular carcinoma (HCC). However, the HCC risk seems to mainly depend on HBsAg positivity. In their 2018 hepatitis B guideline, the AASLD notes an increased risk of HCC in only a small subset of HBsAg-negative patients who are anti-HBc positive, with or without anti-HBs [61]. Among intermediate- to high-risk populations, one can distinguish between the majority of anti- $\mathrm{HBc}(+), \operatorname{HBsAg}(-)$ patients who recovered from acute CHB earlier in life, in whom the risk of $\mathrm{HCC}$ due to $\mathrm{HBV}$ is minimal, and the small subset of patients who had been chronically infected for decades before HBsAg clearance, in whom the risk for HCC is apparently similar to those with persistent HBV infection or hepatitis who have undetectable HBV DNA levels due to the development of liver cirrhosis [61].

\section{Reactivation Risk in Anti-HBc-Positive Patients with Immunosuppression}

Because anti-HBc positivity indicates the continuing presence of HBV cccDNA in the liver, it is an important marker to identify patients who are at risk for $\mathrm{HBV}$ reactivation with immunosuppressive therapy, B cell depleting antibodies or anti-rheumatic drugs [62, 63]. A marked increase in awareness of this issue is needed. However, guidelines are mixed on whether patients with anti-HBc only are at high risk of fatal events. The level of risk in these individuals is not considered high by the American Gastroenterological Association (AGA), which have clearly defined risk categories using the GRADE system (see Table 1) [64, 65]. The American Society for Clinical Oncology provisional guidance, in contrast, considers individuals with anti- $\mathrm{HBc}$ only to be at high risk of reactivation and the potential for fatal events, especially in the setting of cancer therapy with anti-CD20 monoclonal antibodies [66]. Reactivation was an unusual event with earlier immunosuppressive therapies but the risk has increased significantly in recent decades due to increased use of potent immunosuppressive and chemotherapy agents for malignant and non-malignant conditions, including the frequent use of $\mathrm{B}$ cell depleting CD19 and CD20 antibodies [64]. The American Gastroenterological Association (AGA), [65] the European Association for the Study of the Liver (EASL), [3] the Asian
Pacific Association for the Study of the Liver (APASL) [67], and the AASLD [61] recommend testing for HBsAg and anti$\mathrm{HBc}$ in all patients set to receive immunosuppressive therapy or chemotherapy that may induce HBV reactivation. In reality, however, most patients undergoing chemotherapy are not risk-stratified for HBV reactivation, despite the evidence supporting the importance of this issue [64].

The risk of HBV reactivation can be assessed based on positivity for HBV serum biomarkers (HBsAg, anti-HBc, HBV DNA) and the type, duration, combination of agents, and dosing of immunosuppressive or chemotherapeutic agents [64]. HBV reactivation risk can be as high as 40 $70 \%$ in anti-HBc-only, patients who are undergoing chemotherapy with B cell depleting antibodies like rituximab [64].

Noting that reactivation after immunosuppressive therapy is associated with significant morbidity and mortality, the AGA recommends antiviral prophylaxis for patients classified as at either moderate or high risk for reactivation; for low-risk patients, there is no prophylaxis recommendation; monitoring is per provider preference but seemingly sufficient $[64,65]$. Entecavir and tenofovir prodrugs should be used as first-line prophylaxis or therapy due to their stronger antiviral potency and high threshold for resistance.

\section{Anti-HBc in Coinfected Populations}

Coinfection with HBV and hepatitis $\mathrm{C}$ virus (HCV) or hepatitis D virus is known to suppress HBV replication [68] and may occasionally result in anti-HBc only status [7]. In addition, mutations in the $\mathrm{S}$ gene may occur during coinfection [69]. HBV reactivation during or after HCV treatment is possible in these patients. The FDA requires a boxed warning on the labels of all HCV direct-acting antivirals (DAAs) mandating HBV screening and monitoring in all patients receiving DAA treatment [70]. Although HBV reactivation is rare in chronic hepatitis $\mathrm{C}$ patients treated with DAAs, to fully protect patients, thorough $\mathrm{HBV}$ diagnostics is appropriate before starting HCV therapy [31]. If HBV is not treated in those who are known to be coinfected, HBV DNA should be monitored, with initiation of HBV therapy with any rise of HBV DNA, especially if there is a rise in ALT. In individuals who are $\mathrm{HBsAg}$ negative and anti-HBc positive, the risk of HBV reactivation under $\mathrm{HCV}$ direct-acting antivirals and prophylaxis is not recommended but ALT shall be monitored to detect clinically relevant HBV reactivation. The decisionmaking flow chart for this is shown in Fig. 2.

In the HALT-C cohort, neither OBI nor anti-HBc positivity increased HCC incidence in chronic hepatitis $\mathrm{C}$ patients [69]. However, conflicting reports indicated that there may be an increased risk of fibrosis and $\mathrm{HCC}$ in anti-HBc + patients [71]. A recent major review concluded that these conflicting data precludes firm conclusions on the influence of OBI on 
Table 1 American Gastroenterological Association classification of reactivation risk in $\mathrm{HBsAg}(-) / \operatorname{anti}-\mathrm{HBc}(+)$ patients [64]

Reactivation risk Agents used for treatment

High risk: $>10 \%$ estimated incidence of reactivation

Moderate risk: $1 \%-10 \%$ estimated incidence of reactivation

Low risk: $<1 \%$ estimated incidence of reactivation
B cell-depleting agents (e.g., rituximab, ofatumumab)

TNF- $\alpha$ inhibitors (e.g., etanercept, adalimumab, certolizumab, infliximab) Other cytokine inhibitors and integrin inhibitors (e.g., abatacept, ustekinumab, natalizumab, vedolizumab)

Tyrosine kinase inhibitors (e.g., imatinib, nilotinib)

Anthracycline derivatives (e.g., doxorubicin and epirubicin)

Moderate- or high-dose corticosteroids for $\geq 4$ weeks

Traditional immunosuppressive agents (e.g., azathioprine, 6-mercaptopurine, methotrexate)

Intra-articular corticosteroids

Corticosteroid therapy for $\leq 1$ week

Low-dose corticosteroid therapy for $\geq 4$ weeks hepatitis C natural history [72]. HBV and HIV share the same routes of transmission; most HIV-HBV coinfected patients are injection drug users [68]. In HIV-positive patients who experience acute $\mathrm{HBV}$ infection, there is an increased likelihood of progression to $\mathrm{CHB}$, with risk increased by a low CD4 T cell count [73]. In anti-HBc-only patients coinfected with HIV, there is commonly $\mathrm{HBV}$ viremia documented by qHBV DNA PCR [7, 74]. HIV and OBI can also present as fulminant hepatitis [74]. There have been case reports of HBV reactivation in anti-HBc-only HIV-positive patients treated with DAAs [75]. Since anti-HBc only status has been reported in many HIV-positive patients, [76] screening solely for HBsAg would underestimate the prevalence of HIV-HBV coinfection, OBI and HIV-HBV-HCV tri-infection, and the risk of hepatitis B flares. Screening for both anti-HBc and HBsAg significantly increases the probability of finding patients with past exposure to HBV [77]. A full HBV panel including HBsAg, anti-HBs, and anti-HBc is recommended for HIV-positive patients, with any positive HBV biomarker leading to sensitive HBV DNA PCR testing [78, 79]. If there is any evidence of HBV infection, an HIV antiretroviral regimen with HBV coverage such as tenofovir disoproxil fumarate (TDF) or tenofovir alafenamide (TAF) should be considered as firstline therapy [77].
Fig. 2 Project ECHO HBV monitoring for patients on $\mathrm{HCV}$ treatment. Abbreviations: HBV, hepatitis B virus; $\mathrm{HCV}$, hepatitis $\mathrm{C}$ virus; HBsAg, hepatitis B surface antigen; anti-HBc, hepatitis B core antibody; antiHBs, hepatitis B surface antibody; HBV DNA quant, quantitative HBV DNA; ALT, alanine aminotransferase; TDF, tenofovir disoproxil fumarate; ETV, entecavir; DAA, direct-acting antiviral

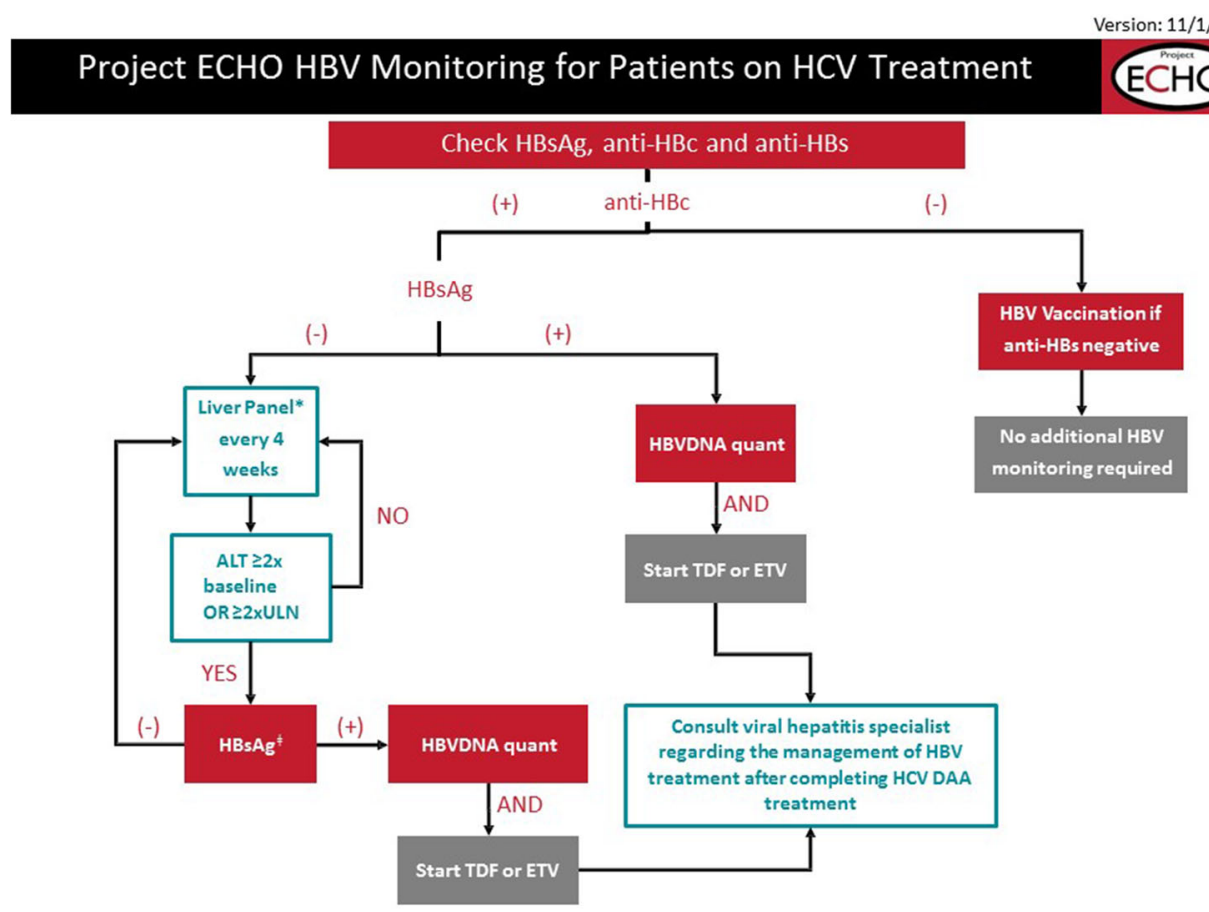

* Liver panel every 4 weeks while on $\mathrm{HCV}$ treatment and at 12 weeks post-treatment.

\# HBsAg can be drawn at the same as HBVDNA for convenience or can ask for HBsAg with reflex HBVDNA. 
Table 2 Considerations on the interpretation of quantitative anti- $\mathrm{HBc}$

\begin{tabular}{|c|c|c|}
\hline Clinical situation & Role of anti-HBc & Comments \\
\hline $\begin{array}{l}\text { Different phases of infection: } \\
\operatorname{HBe} \operatorname{Ag}(+) / \text { high viremia, } \\
\operatorname{HBeAg}(-) \text { infection [93] }\end{array}$ & $\begin{array}{l}\text { qAnti-HBc level higher ( }>\text { tenfold) in low } \\
\text { viremic and } \mathrm{HBeAg}(-) \text { groups compared } \\
\text { to high viremic and phases of infection }\end{array}$ & $\begin{array}{l}\text { qAnti-HBc could be reflective of the current } \\
\text { inflammatory burden and infectivity. Level } \\
\text { also higher in HBV genotype B, occult HBV } \\
\text { infection compared to resolved HBV infection }\end{array}$ \\
\hline qAnti-HBc and liver injury [94] & $\begin{array}{l}\text { qAnti-HBc levels directly correlate to ALT } \\
\text { level and are higher in low viremic, HBe } \\
\mathrm{Ag}(-) \text { phases. qAnti-HBc level is inversely } \\
\text { related to HBsAg levels. }\end{array}$ & $\begin{array}{l}\text { qAnti-HBc level reflects HBV infection with } \\
\text { active liver injury; thus, higher anti-HBc level } \\
\text { is reflected by higher level of ALT. qAnti-HBc } \\
\text { level could be helpful in CHB patients to } \\
\text { differentiate whether higher ALT is secondary } \\
\text { to CHB or development of resistance to } \\
\text { therapy versus other etiologies. }\end{array}$ \\
\hline Predictive of treatment response [95] & $\begin{array}{l}\text { Baseline anti-HBc level and HBV levels } \\
\text { could predict treatment response. }\end{array}$ & $\begin{array}{l}\text { Baseline qAnti-HBC of } \geq 4.4 \log _{10} \mathrm{IU} / \mathrm{mL} \text { and } \\
\text { HBV DNA of }<9 \log _{10} \text { copies } / \mathrm{ml} \text {, or baseline } \\
\text { qAnti-HBc of } \geq 30,000 \mathrm{IU} / \mathrm{mL} \text { could predict } \\
\text { better response to currently approved first } \\
\text { line therapies. }\end{array}$ \\
\hline $\begin{array}{l}\text { Predicting HBV reactivation } \\
\text { during immune suppression [96] }\end{array}$ & $\begin{array}{l}\text { Levels of anti-HBc can be used to predict } \\
\text { HBV reactivation during chemotherapy }\end{array}$ & $\begin{array}{l}\text { Levels of Anti-HBc should be combined with } \\
\text { levels of anti-HBs as a useful predictor of } \\
\text { chemotherapy-induced reactivation }\end{array}$ \\
\hline $\begin{array}{l}\text { Differentiation of acute vs } \\
\text { chronic hepatitis B [97] }\end{array}$ & $\begin{array}{l}\text { The ratio of S/CO of anti- } \mathrm{HBc} \text { IgM and } \\
\text { HBV DNA level can differentiate between } \\
\text { CHB and acute hepatitis B }\end{array}$ & $\begin{array}{l}\text { When the } \mathrm{S} / \mathrm{CO} \text { of Anti-HBc IgM and HBV } \\
\text { DNA are taken together, sensitivity and } \\
\text { specificity are high }\end{array}$ \\
\hline $\begin{array}{l}\text { Differentiation between acute } \\
\text { hepatitis or associated liver } \\
\text { failure and flares of CHB [98] }\end{array}$ & $\begin{array}{l}\text { Can be differentiated by IgM level, VL, } \\
\text { and ratio of anti-HBc/VL }\end{array}$ & $\begin{array}{l}\text { Acute infection-associated liver failure has } \\
\text { significantly higher IgM anti-HBc, lower VL, } \\
\text { and high IgM anti-HBc/ VL ratio compared } \\
\text { to CHB-associated liver failure }\end{array}$ \\
\hline $\begin{array}{l}\text { Predicting natural clearance of } \\
\text { HBsAg from the blood [47] }\end{array}$ & $\begin{array}{c}\text { Associated levels of anti-HBc }<3 \log \mathrm{IU} / \mathrm{mL} \\
\text { with undetectable } \mathrm{HBV} \text { DNA and } \mathrm{HBsAg} \\
\text { seroclearance occurring within } 10 \text { years }\end{array}$ & $\begin{array}{l}\text { Asian population; no nucleotide therapy; } \\
\text { prediction of } \mathrm{HBs} \text { Ag clearance if } \mathrm{HBsAg} \\
\text { quant }<10^{2} \text { at baseline }\end{array}$ \\
\hline
\end{tabular}

$Q$ quantitative; $S$ sample; $C O$ cutoff; $A H B$ acute hepatitis B; $V L$ viral load

Table 3 Interpretation of HBV biomarkers

\begin{tabular}{|c|c|c|c|c|c|}
\hline HBsAg & Anti-HBs & Anti-HBc IgG & Anti-HBc IgM & Interpretation & Comment \\
\hline- & - & - & - & $\begin{array}{l}\text { - HBV-naive } \\
\text { - No or insufficient vaccination }\end{array}$ & $\begin{array}{l}\text { Needs vaccination to decrease HBV } \\
\text { infection risk }\end{array}$ \\
\hline+ & - & + & + & $\begin{array}{l}\text { Acute HBV infection or active } \\
\text { hepatitis flare in a chronic HBV patient }\end{array}$ & $\begin{array}{l}\text { - Control ALT levels in short-term intervals } \\
\text { - Wait } 6 \text { months; repeat HBV panel }\end{array}$ \\
\hline+ & - & + & - & Chronic HBV infection & Evaluate patient for treatment \\
\hline- & + & - & - & Protective immunity (after vaccination) & Titer $\geq 100 \mathrm{IU} / 1$ is desirable \\
\hline- & - & + & - & $\begin{array}{l}\text { - Recovered from HBV infection } \\
\text { with incomplete immune control } \\
\text { - Anti-HBs titer }<10 \mathrm{IU} / \mathrm{L} \\
\text { - Risk of reactivation under immune } \\
\text { suppression } \\
\text { - May transmit HBV with liver or } \\
\text { bone marrow transplant }\end{array}$ & $\begin{array}{l}\text { - Observe the patient } \\
\text { - Needs HBV DNA PCRs if undergoing } \\
\text { chemotherapy or immune suppression } \\
\text { or elevated ALT } \\
\text { - Low risk of transmission only in } \\
\text { special situations }\end{array}$ \\
\hline- & + & + & - & $\begin{array}{l}\text { - Recovered from past HBV infection } \\
\text { - Low risk of HBV reactivation }\end{array}$ & $\begin{array}{l}\text { - Observe the patient } \\
\text { - Might need HBV DNA PCRs if } \\
\text { undergoing chemotherapy or immune } \\
\text { suppression } \\
\text { - Negligible risk of transmission under } \\
\text { normal conditions }\end{array}$ \\
\hline
\end{tabular}




\section{Anti-HBc Status: Liver Transplant Setting}

In HBsAg-negative patients who receive a liver transplant from an anti-HBc-positive donor, there is a risk of HBV infection and recipient seroconversion, depending on the recipient's anti-HBc and anti-HBs status [80]. In a retrospective study of 207 patients HBsAg-negative prior to transplant from anti-HBc + donors, 20 were found to be HBsAg-positive posttransplant; 19 had post-transplant HBV DNA in their serum [81]. In studies, $50 \%$ [82•] or $31.8 \%$ [83•] of HBV serum biomarker-negative recipients receiving anti-HBc-positive liver grafts developed HBV infection post-transplant. In the latter study, this did not influence patient or graft survival, and further analysis showed that positive anti-HBs status in the recipient was protective. In a recent retrospective study from Hong Kong on outcomes from 964 liver transplants, transplantation of anti-HBc positive liver grafts did not negatively impact HCC recurrence or survival of the patient or graft [84]. In the setting of kidney transplantation, the risk of transmission from an anti-HBc + donor is markedly lower than for liver transplantation [85].

Including anti-HBc for screening, not only blood but in particular organ donors is vital [37,86-91]. To decrease HBV transmission or allow immune control, recipients who are HBV-negative should be vaccinated against HBV before organ and in particular before liver transplant [82]. Anti-HBcpositive recipients can receive allografts from anti-HBcpositive donors with ongoing nucleos(t)ide treatment. In case of mismatch, where recipient is negative for serum HBV markers and donor is anti-HBc-positive, the recipient should be treated with long-term prophylactic antiviral treatment [92]. In the setting of kidney transplantation, up to 1 year of prophylaxis may be considered in susceptible recipients but is not recommended for immune recipients [85].

\section{Conclusions}

It is crucially important for clinicians to understand the importance of screening patients to determine the anti-HBc status, proper interpretation of HBV biomarkers (see Tables 2 and 3), and that "anti-HBc only" indicates exposure to HBV, lifelong persistence of cccDNA with incomplete control of infection, and risk for reactivation under strong immunosuppression. Clinicians also need to be aware of common misconceptions, including that the core antibody has a high false-positive rate. This is definitively not true when current generation tests that have very high sensitivity and specificity and very low false-positive rates $(<2 / 1000)$ are used. Another misconception is that patients with anti-HBc only status or OBI need "vaccine boosting" to provide "protection" from infection as there is no direct evidence to support this. It is also very important to expand understanding among both clinicians and patients that HBV reactivation is a risk in individuals requiring HCV DAA therapy, chemotherapy, or potent immunosuppressive therapy. Despite the substantial body of evidence demonstrating the risk of reactivation, this too often goes unaddressed in clinical settings where patients are not screened for HBV infection prior to initiation of such therapies and thus do not receive appropriate prophy- laxis. Careful screening of liver transplant recipients and organ donors for anti-HBc, with appropriate follow up including transplant recipient vaccination where appropriate, is also absolutely necessary. As our understanding of the usefulness of anti-HBc levels expands (Table 2), they should also be considered in research settings, and ultimately clinical utility may expand.

\section{Compliance with Ethical Standards}

Conflict of Interest No relevant disclosures for Abdul Basit, Ryan, or Dawood. Dr. Protzer has disclosed that she has been an Advisor of AbbVie, Dicerna, GSK, MSD, and Vaccitech; has current activity with the scientific or clinical advisory boards of Arbutus Biopharma and Gilead; received scientific funding from Alios-J\&J, Roche, and VIR Biotechnology; has been a member of the supervisory board, and is the cofounder, board member, and receives grant support from SCG Cell Therapy. Dr. Gish has disclosed that he has received grant support from Gilead; has been a consultant and/or advisor to Abbott, AbbVie, Access Biologicals, Alexion, Antios, Arrowhead Research Corporation, Bayer AG, Bristol-Myers Squibb, Eiger, Eisai, Enyo Pharma, eStudySite, Forty-Seven Inc., Genlantis, Gerson Lehrman Group, Gilead Sciences, HepaTX, HepQuant, Intercept, Ionis Pharmaceuticals, Janssen, Laboratory for Advanced Medicine, Lilly, Merck, Salix, Shionogi, Trimaran, Viking Therapeutics; has current activity with the scientific or clinical advisory boards of Abbott, AbbVie, Arrowhead, Bayer, Dova Pharmaceuticals, Eiger, Enyo, Hatch BioFund, HepQuant, Intercept, Janssen, and MedImmune; is an advisory consultant for Biocollections, Fujifilm/Wako, and Quest; is on the Data Safety Monitoring Board for Eiger and Ionis; is a member of the Speakers Bureau for AbbVie, Bayer, Bristol-Myers Squibb, Dova, Eisai, Gilead Sciences, Intercept, Salix, and Shionogi; and has stock options with AngioCrine, Eiger BioPharma, and HepQuant.

Human and Animal Rights This article does not contain any studies with human or animal subjects performed by any of the authors.

Open Access This article is licensed under a Creative Commons Commons Attribution 4.0 International License, which permits use, sharing, adaptation, distribution and reproduction in any medium or format, as long as you give appropriate credit to the original author(s) and the source, provide a link to the Creative Commons license, and indicate if changes were made.

The images or other third party material in this article are included in the article's Creative Commons licence, unless indicated otherwise in a credit line to the material. If material is not included in the article's Creative Commons licence and your intended use is not permitted by statutory regulation or exceeds the permitted use, you will need to obtain permission directly from the copyright holder. To view a copy of this licence, visit http://creativecommons.org/licenses/by/4.0/.

\section{References}

Papers of particular interest, published recently, have been highlighted as:

- Of importance

•. Of major importance

1. Thomas DL. Global elimination of chronic hepatitis. N Engl J Med. 2019;380(21):2041-50. https://doi.org/10.1056/NEJMra1810477.

2. Seto WK, Lo YR, Pawlotsky JM, Yuen MF. Chronic hepatitis B virus infection. Lancet. 2018;392(10161):2313-24. https://doi.org/ 10.1016/S0140-6736(18)31865-8.

3. European Association for the Study of the Liver. EASL 2017 clinical practice guidelines on the management of hepatitis B virus 
infection. J Hepatol. 2017;67(2):370-98. https://doi.org/10.1016/j. jhep.2017.03.021.

4. Abbott Laboratories. ABBOTT PRISM HBcore list no. 6E66. 34 3831/R9 ABBOTT PRISM hepatitis B virus core antigen (E. coli, recombinant). Abbott Park, IL: Abbott Laboratories.

5. Ilboudo CM, Guest EM, Ferguson AM, Garg U, Jackson MA. Misleading hepatitis B testing in the setting of intravenous immunoglobulin. F1000Research. 2013;2:249. https://oi.org/10.12688/ f1000research.2-249.v1.

6. Gessoni G, Beggio S, Barin P, Favarato M, Galli C, Valverde S, et al. Significance of anti-HBc only in blood donors: a serological and virological study after hepatitis B vaccination. Blood Transfus. 2014;12(Suppl 1):s63-8. https://doi.org/10.2450/2013.0227-12.

7. Grob P, Jilg W, Bornhak H, Gerken G, Gerlich W, Gunther S, et al. Serological pattern "anti-HBc alone": report on a workshop. J Med Virol. 2000;62(4):450-5.

8. Wang Q, Klenerman P, Semmo N. Significance of anti-HBc alone serological status in clinical practice. Lancet Gastroenterol Hepatol. 2017;2(2):123-34. https://doi.org/10.1016/S2468-1253(16)300760.

9.• Lok AS, Zoulim F, Dusheiko G, Ghany MG. Hepatitis B cure: from discovery to regulatory approval. Hepatology. 2017;66(4):1296313. https://doi.org/10.1002/hep.29323. Important recent comprehensive review of occult $\mathrm{HBV}$ infection, including understanding of $\mathrm{HBV}$ serum markers such as anti-HBc.

10. Raimondo G, Locarnini S, Pollicino T, Levrero M, Zoulim F, Lok AS, et al. Update of the statements on biology and clinical impact of occult hepatitis B virus infection. J Hepatol. 2019;71(2):397-408. https://doi.org/10.1016/j.jhep.2019.03.034.

11. Yuen MF, Wong DKH, Fung J, Ip P, But D, Hung I, et al. HBsAg seroclearance in chronic hepatitis B in Asian patients: replicative level and risk of hepatocellular carcinoma. Gastroenterology. 2008;135(4):1192-9.

12. Yuen M-F, Ahn SH, Chen D-S, Chen P-J, Dusheiko GM, Hou J-L, et al. Chronic hepatitis B virus infection: disease revisit and management recommendations. J Clin Gastroenterol. 2016;50(4):28694.

13. Lai CL, Wong D, Ip P, Kopaniszen M, Seto WK, Fung J, et al. Reduction of covalently closed circular DNA with long-term nucleos $(\mathrm{t})$ ide analogue treatment in chronic hepatitis B. J Hepatol. 2017;66(2):275-81. https://doi.org/10.1016/j.jhep.2016.08.022.

14. Revill P, Testoni B, Locarnini S, Zoulim F. Global strategies are required to cure and eliminate $\mathrm{HBV}$ infection. Nat Rev Gastroenterol Hepatol. 2016;13(4):239-48. https://doi.org/10. 1038/nrgastro.2016.7.

15. Lucifora J, Protzer U. Attacking hepatitis B virus cccDNA-the holy grail to hepatitis B cure. J Hepatol. 2016;64(1 Suppl):S41-8. https:// doi.org/10.1016/j.jhep.2016.02.009.

16. Liang TJ, Block TM, McMahon BJ, Ghany MG, Urban S, Guo JT, et al. Present and future therapies of hepatitis B: from discovery to cure. Hepatology. 2015;62(6):1893-908.

17. Wooddell CI, Yuen MF, Chan HL, Gish RG, Locarnini SA, Chavez $\mathrm{D}$ et al. RNAi-based treatment of chronically infected patients and chimpanzees reveals that integrated hepatitis B virus DNA is a source of HBsAg. Sci Transl Med. 2017;9(409). https://doi.org/ 10.1126/scitranslmed.aan0241.

18. Revill PA, Chisari FV, Block JM, Dandri M, Gehring AJ, Guo H, et al. A global scientific strategy to cure hepatitis B. Lancet Gastroenterol Hepatol. 2019;4(7):545-58. https://doi.org/10.1016/ S2468-1253(19)30119-0.

19. McMahon BJ, Alward WL, Hall DB, Heyward WL, Bender TR, Francis DP, et al. Acute hepatitis B virus infection: relation of age to the clinical expression of disease and subsequent development of the carrier state. J Infect Dis. 1985;151(4):599-603.

20. Yi P, Chen R, Huang Y, Zhou RR, Fan XG. Management of mother-to-child transmission of hepatitis $\mathrm{B}$ virus: propositions and challenges. J Clin Virol. 2016;77:32-9. https://doi.org/10. 1016/j.jcv.2016.02.003

21. Ganem D, Prince AM. Hepatitis B virus infection-natural history and clinical consequences. N Engl J Med. 2004;350(11):1118-29. https://doi.org/10.1056/NEJMra031087.

22. Hoofnagle JH. Serologic markers of hepatitis B virus infection. Annu Rev Med. 1981;32:1-11. https://doi.org/10.1146/annurev. me.32.020181.000245.

23. Park JW, Kwak KM, Kim SE, Jang MK, Kim DJ, Lee MS, et al. Differentiation of acute and chronic hepatitis B in IgM anti-HBc positive patients. World J Gastroenterol. 2015;21(13):3953-9. https://doi.org/10.3748/wjg.v21.i13.3953.

24. Galli C, Orlandini E, Penzo L, Badiale R, Caltran G, Valverde S, et al. What is the role of serology for the study of chronic hepatitis $\mathrm{B}$ virus infection in the age of molecular biology? J Med Virol. 2008;80(6):974-9. https://doi.org/10.1002/jmv.21179.

25. Rodella A, Galli C, Terlenghi L, Perandin F, Bonfanti C, Manca N. Quantitative analysis of $\mathrm{HBs} \mathrm{Ag}$, IgM anti-HBc and anti-HBc avidity in acute and chronic hepatitis B. J Clin Virol. 2006;37(3):20612. https://doi.org/10.1016/j.jcv.2006.06.011.

26. Song JE, Kim DY. Diagnosis of hepatitis B. Ann Transl Med. 2016;4(18). doi:https://doi.org/10.21037/atm.2016.09.11.

27. Zoulim F. New insight on hepatitis B virus persistence from the study of intrahepatic viral cccDNA. J Hepatol. 2005;42(3):302-8. https://doi.org/10.1016/j.jhep.2004.12.015.

28. Li X, Zhao J, Yuan Q, Xia N. Detection of HBV covalently closed circular DNA. Viruses. 2017;9(6). https://doi.org/10.3390/ v9060139.

29. Yang HC, Kao JH. Persistence of hepatitis B virus covalently closed circular DNA in hepatocytes: molecular mechanisms and clinical significance. Emerg Microbes Infect. 2014;3(9) e64:1-7. https://doi.org/10.1038/emi.2014.64.

30. Ponde RA, Cardoso DD, Ferro MO. The underlying mechanisms for the 'anti-HBc alone' serological profile. Arch Virol. 2010;155(2):149-58. https://doi.org/10.1007/s00705-009-0559-6.

31. Terrault NA, Lok ASF, McMahon BJ, Chang KM, Hwang JP, Jonas MM, et al. Update on prevention, diagnosis, and treatment of chronic hepatitis B: AASLD 2018 hepatitis B guidance. Hepatology. 2018;67(4):1560-99. https://doi.org/10.1002/hep. 29800.

32. Pan CQ, Duan Z, Dai E, Zhang S, Han G, Wang Y, et al. Tenofovir to prevent hepatitis $B$ transmission in mothers with high viral load. N Engl J Med. 2016;374(24):2324-34. https://doi.org/10.1056/ NEJMoa1508660.

33. Hoofnagle JH, Seeff LB, Bales ZB, Zimmerman HJ. Type B hepatitis after transfusion with blood containing antibody to hepatitis $B$ core antigen. N Engl J Med. 1978;298(25):1379-83. https://doi.org/ 10.1056/nejm197806222982502. Important study evaluating blood donation safety from occult HBV infection and the role of anti-HBc testing.

34. Candotti D, Assennato SM, Laperche S, Allain JP, LevicnikStezinar S. Multiple HBV transfusion transmissions from undetected occult infections: revising the minimal infectious dose. Gut. 2018;68:313-21. https://doi.org/10.1136/gutjnl-2018-316490.

35. Taira R, Satake M, Momose S, Hino S, Suzuki Y, Murokawa H, et al. Residual risk of transfusion-transmitted hepatitis B virus (HBV) infection caused by blood components derived from donors with occult HBV infection in Japan. Transfusion. 2013;53(7): 1393-404. https://doi.org/10.1111/j.1537-2995.2012.03909.x.

36. Tani Y, Aso H, Matsukura H, Tadokoro K, Tamori A, Nishiguchi $\mathrm{S}$, et al. Significant background rates of HBV and HCV infections in patients and risks of blood transfusion from donors with low anti$\mathrm{HBc}$ titres or high anti-HBc titres with high anti-HBs titres in Japan: a prospective, individual NAT study of transfusion-transmitted HBV. HCV and HIV infections Vox Sang. 2012;102(4):285-93. https://doi.org/10.1111/j.1423-0410.2011.01561.x. 
37. Kiely P, Margaritis AR, Seed CR, Yang H. Hepatitis B virus nucleic acid amplification testing of Australian blood donors highlights the complexity of confirming occult hepatitis B virus infection. Transfusion. 2014;54(8):2084-91. https://doi.org/10.1111/trf. 12556.

38. Kleinman SH, Kuhns MC, Todd DS, Glynn SA, McNamara A, DiMarco A, et al. Frequency of HBV DNA detection in US blood donors testing positive for the presence of anti-HBc: implications for transfusion transmission and donor screening. Transfusion. 2003;43(6):696-704.

39. Velati C, Fomiatti L, Baruffi L, Piccinini V, Prati D, Reina A, et al. Criteria for hepatitis B virus screening and validation of blood components in Italy: the position of the SIMTI HBV working group. Blood Transfus. 2011;9(4):455-61. https://doi.org/10.2450/2011. 0014-11.

40. Allain JP, Hewitt PE, Tedder RS, Williamson LM. Evidence that anti-HBc but not HBV DNA testing may prevent some HBV transmission by transfusion. Br J Haematol. 1999;107(1):186-95.

41. World Health Organization. Screening donated blood for transfusion-transmissible infections. https://www.who.int/ bloodsafety/publications/bts_screendondbloodtransf/en/ Important analysis from 10-year German surveillance program demonstrating importance of anti-HBc screening for blood supply safety.

42. Houareau C, Offergeld R. Anti-HBc screening - is it worth the effort? Results of a 10-year surveillance programme covering more than 30 million donations in Germany. Vox Sang. 2019;114(5): 459-66. https://doi.org/10.1111/vox.12781.

43. Ye X, Li T, Shao W, Zeng J, Hong W, Lu L et al. Nearly half of Ultrio plus NAT non-discriminated reactive blood donors were identified as occult HBV infection in South China. BMC Infect Dis. 2019;19(1):574. https://doi.org/10.1186/s12879-019-4215-9. Japanese study identifying segment of anti-HBc positive blood which may be safe for donation based on anti-HBs titers.

44. Hoshi Y, Hasegawa T, Yamagishi N, Mizokami M, Sugiyama M, Matsubayashi K, et al. Optimal titer of anti-HBs in blood components derived from donors with anti-HBc. Transfusion. 2019;59: 2602-11. https://doi.org/10.1111/trf.15393.

45. Seiskari T, Lehtisaari H, Haapala AM, Aittoniemi J. From Abbott ARCHITECT anti-HBc to anti-HBc II-improved performance in detecting antibodies to hepatitis B core antigen. J Clin Virol. 2010;47(1):100-1. https://doi.org/10.1016/j.jcv.2009.11.010.

46. Yuan Q, Song LW, Cavallone D, Moriconi F, Cherubini B, Colombatto P et al. Total hepatitis B core antigen antibody, a quantitative non-invasive marker of hepatitis B virus induced liver disease. PLoS One. 2015;10(6):e0130209. https://doi.org/10.1371/ journal.pone.0130209. Large retrospective analysis from Taiwan identifying combination of seromarkers to predict $\mathrm{HBsAg}$ seroclearance among $\mathrm{HBeAg}$-negative patients.

47. Hu HH, Liu J, Chang CL, Jen CL, Lee MH, Lu SN, et al. Level of hepatitis $\mathrm{B}(\mathrm{HB})$ core antibody associates with seroclearance of HBV DNA and HB surface antigen in HB e antigen-seronegative patients. Clin Gastroenterol Hepatol. 2019;17(1):172-81 e1. https:// doi.org/10.1016/j.cgh.2018.04.064.

48. Rehermann B, Ferrari C, Pasquinelli C, Chisari FV. The hepatitis B virus persists for decades after patients' recovery from acute viral hepatitis despite active maintenance of a cytotoxic T-lymphocyte response. Nat Med. 1996;2(10):1104-8. https://doi.org/10.1038/ nm1096-1104.

49. Vandepapeliere P, Lau GK, Leroux-Roels G, Horsmans Y, Gane E, Tawandee $\mathrm{T}$, et al. Therapeutic vaccination of chronic hepatitis B patients with virus suppression by antiviral therapy: a randomized, controlled study of co-administration of $\mathrm{HBsAg} / \mathrm{ASO} 2$ candidate vaccine and lamivudine. Vaccine. 2007;25(51):8585-97. https:// doi.org/10.1016/j.vaccine.2007.09.072.
50. Xu DZ, Wang XY, Shen XL, Gong GZ, Ren H, Guo LM, et al. Results of a phase III clinical trial with an HBsAg-HBIG immunogenic complex therapeutic vaccine for chronic hepatitis B patients: experiences and findings. J Hepatol. 2013;59(3):450-6. https://doi. org/10.1016/j.jhep.2013.05.003.

51. Shouval D, Roggendorf H, Roggendorf M. Enhanced immune response to hepatitis B vaccination through immunization with a preS1/pre-S2/S vaccine. Med Microbiol Immunol. 2015;204(1):5768. https://doi.org/10.1007/s00430-014-0374-x.

52. Kosinska AD, Bauer T, Protzer U. Therapeutic vaccination for chronic hepatitis B. Curr Opin Virol. 2017;23:75-81. https://doi. org/10.1016/j.coviro.2017.03.011.

53. Paul S, Dickstein A, Saxena A, Terrin N, Viveiros K, Balk EM, et al. Role of surface antibody in hepatitis $B$ reactivation in patients with resolved infection and hematologic malignancy: a meta-analysis. Hepatology. 2017;66(2):379-88. https://doi.org/10.1002/hep. 29082.

54. O'Brien SF, Fearon MA, Yi QL, Fan W, Scalia V, Muntz IR, et al. Hepatitis B virus DNA-positive, hepatitis B surface antigennegative blood donations intercepted by anti-hepatitis B core antigen testing: the Canadian blood services experience. Transfusion. 2007;47(10):1809-15. https://doi.org/10.1111/j.1537-2995.2007. 01396.x.

55. Zhu HL, Li X, Li J, Zhang ZH. Genetic variation of occult hepatitis B virus infection. World J Gastroenterol. 2016;22(13):3531-46. https://doi.org/10.3748/wjg.v22.i13.3531.

56. Raimondo G, Allain JP, Brunetto MR, Buendia MA, Chen DS, Colombo M, et al. Statements from the Taormina expert meeting on occult hepatitis B virus infection. J Hepatol. 2008;49(4):652-7. https://doi.org/10.1016/j.jhep.2008.07.014.

57. Lusida MI, Surayah, Sakugawa H, Nagano-Fujii M, Soetjipto, Mulyanto et al. Genotype and subtype analyses of hepatitis B virus (HBV) and possible co-infection of HBV and hepatitis $\mathrm{C}$ virus (HCV) or hepatitis D virus (HDV) in blood donors, patients with chronic liver disease and patients on hemodialysis in Surabaya, Indonesia. Microbiol Immunol 2003;47(12):969-975. https://doi. org/10.1111/j.1348-0421.2003.tb03457.x.

58. Joller-Jemelka HI, Wicki AN, Grob PJ. Detection of HBs antigen in "anti-HBc alone" positive sera. J Hepatol. 1994;21(2):269-72.

59. Sugg U, Erhardt S, Schneider W. Chronic "low-level" hepatitis B virus carrier with probable infectivity. Lancet. 1982;1(8269):446-7.

60. Lu H, Lok AS, Warneke CL, Ahmed S, Torres HA, Martinez F et al. Passive transfer of anti-HBc after intravenous immunoglobulin administration in patients with cancer: a retrospective chart review. The Lancet Haematology. 2018;5(10):e474-e8. https://doi. org/10.1016/S2352-3026(18)30152-2. Systematic review highlighting risk of $\mathrm{HBV}$ reactivation and need for prophylaxis among HBsAg-negative, anti-HBc-positive patients receiving immunosuppressive therapy.

61. Terrault NA, Lok AS, McMahon BJ, Chang KM, Hwang JP, Jonas $\mathrm{MM}$, et al. Update on prevention, diagnosis, and treatment and of chronic hepatitis B: AASLD 2018 hepatitis B guidance. Hepatology. 2018;67:1560-99. https://doi.org/10.1002/hep.29800.

62. Cholongitas E, Haidich AB, Apostolidou-Kiouti F, Chalevas P, Papatheodoridis GV. Hepatitis B virus reactivation in HBsAg-negative, anti-HBc-positive patients receiving immunosuppressive therapy: a systematic review. Ann Gastroenterol. 2018;31(4):480 90. https://doi.org/10.20524/aog.2018.0266.

63. Schwaneck EC, Krone M, Kreissl-Kemmer S, Weissbrich B, Weiss $\mathrm{J}$, Tony HP, et al. Management of anti-HBc-positive patients with rheumatic diseases treated with disease-modifying antirheumatic drugs-a single-center analysis of 2054 patients. Clin Rheumatol. 2018;37:2963-70. https://doi.org/10.1007/s10067-018-4295-8.

64. Perrillo RP, Gish R, Falck-Ytter YT. American Gastroenterological Association Institute technical review on prevention and treatment of hepatitis B virus reactivation during immunosuppressive drug 
therapy. Gastroenterology. 2015;148(1):221-44 e3. https://doi.org/ 10.1053/j.gastro.2014.10.038.

65. Reddy KR, Beavers KL, Hammond SP, Lim JK, Falck-Ytter YT, American Gastroenterological Association I. American Gastroenterological Association Institute guideline on the prevention and treatment of hepatitis B virus reactivation during immunosuppressive drug therapy. Gastroenterology. 2015;148(1):215-9; quiz e16-7. doi:https://doi.org/10.1053/j.gastro.2014.10.039.

66. Hwang JP, Artz AS, Somerfield MR. Hepatitis B virus screening for patients with cancer before therapy: American Society of Clinical Oncology provisional clinical opinion update. Journal of oncology practice. 2015;11(4):e487-9. https://doi.org/10.1200/ JOP.2015.004846

67. Sarin SK, Kumar M, Lau GK, Abbas Z, Chan HL, Chen CJ, et al. Asian-Pacific clinical practice guidelines on the management of hepatitis B: a 2015 update. Hepatol Int. 2016;10(1):1-98. https:// doi.org/10.1007/s12072-015-9675-4.

68. Makvandi M. Update on occult hepatitis B virus infection. World J Gastroenterol. 2016;22(39):8720-34.

69. Lok AS, Everhart JE, Di Bisceglie AM, Kim H-Y, Hussain M, Morgan TR, et al. Occult and previous hepatitis B virus infection are not associated with hepatocellular carcinoma in United States patients with chronic hepatitis C. Hepatology. 2011;54(2):434-42. https://doi.org/10.1002/hep.24257.

70. Food and Drug Administration. FDA drug safety communication: FDA warns about the risk of hepatitis B reactivating in some patients treated with direct-acting antivirals for hepatitis C. 2006. https://www.fda.gov/drugs/drug-safety-and-availability/fda-drugsafety-communication-fda-warns-about-risk-hepatitis-breactivating-some-patients-treated.

71. Jakab SS. Liver and pancreatic cancer related to hepatitis B exposure: has the jury reached a verdict? J Clin Gastroenterol. $2014 ; 48(8): 655-6$. https://doi.org/10.1097/mcg. 0000000000000163

72. Coppola N, Onorato L, Pisaturo M, Macera M, Sagnelli C, Martini $\mathrm{S}$, et al. Role of occult hepatitis B virus infection in chronic hepatitis C. World J Gastroenterol. 2015;21(42):11931-40. https://doi.org/ 10.3748/wjg.v21.i42.11931.

73. Mallet V, Vallet-Pichard A, Pol S. The impact of human immunodeficiency virus on viral hepatitis. Liver Int. 2011;31:135-9. https:// doi.org/10.1111/j.1478-3231.2010.02394.x.

74. Mphahlele MJ, Lukhwareni A, Burnett RJ, Moropeng LM, Ngobeni JM. High risk of occult hepatitis B virus infection in HIV-positive patients from South Africa. J Clin Virol.35(1):14 20. https://doi.org/10.1016/j.jcv.2005.04.003.

75. Fabbri G, Mastrorosa I, Vergori A, Mazzotta V, Pinnetti C, Grisetti $\mathrm{S}$, et al. Reactivation of occult HBV infection in an HIV/HCV coinfected patient successfully treated with sofosbuvir/ledipasvir: a case report and review of the literature. BMC Infect Dis. 2017;17(1):182. https://doi.org/10.1186/s12879-017-2287-y.

76. Neau D, Winnock M, Galpérine T, Jouvencel AC, Castéra L, Legrand $\mathrm{E}$, et al. Isolated antibodies against the core antigen of hepatitis B virus in HIV-infected patients. HIV Med. 2004;5(3): 171-3. https://doi.org/10.1111/j.1468-1293.2004.00206.x.

77. Firnhaber C, Viana R, Reyneke A, Schultze D, Malope B, Maskew $\mathrm{M}$, et al. Occult hepatitis B virus infection in patients with isolated core antibody and HIV co-infection in an urban clinic in Johannesburg. South Africa Int J Infect Dis. 2009;13(4):488-92.

78. Michèle LP, Marielle G, Michel B, Henri D, Chavanet PP. Hepatitis $B$ virus seroconversion in HIV-HBV coinfected patients treated with highly active antiretroviral therapy. J Acquir Immune Defic Syndr. 2000;23(4):356-7.

79. Chook JB, Teo WL, Ngeow YF, Tee KK, Ng KP, Mohamed R. Universal primers for detection and sequencing of hepatitis $\mathrm{B}$ virus genomes across genotypes A to G. J Clin Microbiol. 2015;53(6): 1831-5. https://doi.org/10.1128/JCM.03449-14.
80. Knöll A, Pietrzyk M, Loss M, Goetz WA, Jilg W. Solid-organ transplantation in HBsAg-negative patients with antibodies to HBV core antigen: low risk of HBV reactivation. Transplantation. 2005;79(11):1631-3.

81. Chazouilleres O, Mamish D, Kim M, Carey K, Wright T, Ferrell L et al. "Occult" hepatitis B virus as source of infection in liver transplant recipients. Lancet. 1994;343(8890):142-146, "Occult" hepatitis B virus as source of infection in liver transplant recipients.

82. Prieto M, Gómez MD, Berenguer M, Córdoba J, Rayón JM, Pastor $\mathrm{M}$ et al. De novo hepatitis B after liver transplantation from hepatitis B core antibody - positive donors in an area with high prevalence of anti-HBc positivity in the donor population. Liver Transpl. 2001;7(1):51-8. Retrospective analysis showing feasibility of $\mathrm{HBcAb}$-positive liver grafts for transplantation.

83. Lei M, Yan LN, Yang JY, Wen TF, Li B, Wang WT et al. Safety of hepatitis B virus core antibody-positive grafts in liver transplantation: a single-center experience in China. World J Gastroenterol. 2018;24(48):5525-36. https://doi.org/10.3748/wjg.v24.i48.5525. Analysis of antiviral prophylaxis when transplanting anti-HBcpositive grafts for liver transplantation.

84. Wong TC, Fung JY, Cui TY, Lam AH, Dai JW, Chan AC, et al. Liver transplantation using hepatitis B core positive grafts with antiviral monotherapy prophylaxis. J Hepatol. 2019;70(6):1114 22. https://doi.org/10.1016/j.jhep.2019.03.003.

85. Huprikar S, Danziger-Isakov L, Ahn J, Naugler S, Blumberg E, Avery RK, et al. Solid organ transplantation from hepatitis B virus-positive donors: consensus guidelines for recipient management. Am J Transplant. 2015;15(5):1162-72. https://doi.org/10. 1111/ajt.13187.

86. van de Laar TJ, Marijt-van der Kreek T, Molenaar-de Backer MW, Hogema BM, Zaaijer HL. The yield of universal antibody to hepatitis B core antigen donor screening in the Netherlands, a hepatitis B virus low-endemic country. Transfusion. 2015;55(6):1206-1213. https://doi.org/10.1111/trf.12962.

87. Muselmani W, Habbal W, Monem F. Significance of screening antibodies to hepatitis B virus core antigen among Syrian blood donors. Transfus Med. 2013;23(4):265-8. https://doi.org/10.1111/ tme.12043.

88. Ba Alawi F, Robertson PW, LePage AK, Jayamaha J, Baleriola C, Rawlinson WD. The reliability of HBV core antibody in serological screening for hepatitis B virus. Pathology. 2013;45(5):501-5. https://doi.org/10.1097/PAT.0b013e3283631cf9.

89. De Feo TM, Poli F, Mozzi F, Moretti MP, Scalamogna M. Risk of transmission of hepatitis B virus from anti-HBc positive cadaveric organ donors: a collaborative study. Transplant Proc.37(2):1238-9. https://doi.org/10.1016/j.transproceed.2004.12.041.

90. Dickson RC, Everhart JE, Lake JR, Wei Y, Seaberg EC, Wiesner $\mathrm{RH}$, et al. Transmission of hepatitis B by transplantation of livers from donors positive for antibody to hepatitis B core antigen. The National Institute of Diabetes and Digestive and Kidney Diseases Liver Transplantation Database. Gastroenterology.113(5):166874. https://doi.org/10.1053/gast.1997.v113.pm9352871.

91. Dodson SF, Issa S, Araya V, Gayowski T, Pinna A, Eghtesad B, et al. Infectivity of hepatic allografts with antibodies to hepatitis B virus. Transplantation. 1997;64(11):1582-4.

92. Saab S, Waterman B, Chi AC, Tong MJ. Comparison of different immunoprophylaxis regimens after liver transplantation with hepatitis B core antibody-positive donors: a systematic review. Liver Transpl. 2010;16(3):300-7.

93. Song LW, Liu PG, Liu CJ, Zhang TY, Cheng XD, Wu HL et al. Quantitative hepatitis B core antibody levels in the natural history of hepatitis B virus infection. Clin Microbiol Infect. 2015;21(2):197203. https://doi.org/10.1016/j.cmi.2014.10.002.

94. Li M-R, Lu J-H, Ye L-H, Sun X-L, Zheng Y-H, Liu Z-Q, et al. Quantitative hepatitis B core antibody level is associated with inflammatory activity in treatment-naïve chronic hepatitis B patients. 
Medicine (Baltimore). 2016;95(34):e4422. https://doi.org/10.1097/ md.0000000000004422.

95. Fan R, Sun J, Yuan Q, Xie Q, Bai X, Ning Q, et al. Baseline quantitative hepatitis $\mathrm{B}$ core antibody titre alone strongly predicts $\mathrm{HBeAg}$ seroconversion across chronic hepatitis B patients treated with peginterferon or nucleos(t)ide analogues. Gut. 2016;65(2): 313-20. https://doi.org/10.1136/gutjnl-2014-308546.

96. Matsubara T, Nishida T, Shimoda A, Shimakoshi H, Amano T, Sugimoto A, et al. The combination of anti-HBc and anti-HBs levels is a useful predictor of the development of chemotherapyinduced reactivation in lymphoma patients with resolved HBV infection. Oncol Lett. 2017;14(6):6543-52. https://doi.org/10.3892/ ol.2017.7012.
97. Puri P. Acute exacerbation of chronic hepatitis B: the dilemma of differentiation from acute viral hepatitis B. J Clin Exp Hepatol. 2013;3(4):301-12. https://doi.org/10.1016/j.jceh.2013.08.014.

98. Dao DY, Hynan LS, Yuan H-J, Sanders C, Balko J, Attar N, et al. Two distinct subtypes of hepatitis B virus-related acute liver failure are separable by quantitative serum immunoglobulin $M$ antihepatitis B core antibody and hepatitis B virus DNA levels. Hepatology. 2012;55(3):676-84. https://doi.org/10.1002/hep. 24732.

Publisher's Note Springer Nature remains neutral with regard to jurisdictional claims in published maps and institutional affiliations. 